\title{
Maturation of the Rabbit Alveolar Macrophage during Animal Development III. Phagocytic and Bactericidal Functions
}

\author{
BARBARA I. ZILLI( BS, WATA S. NERURKAR, AND JOSEPH A. BIIIIANII \\ De'partme'nts of Pediatrics, Microhicology, and the Center for Interdisciplinary Studies of Immunology at \\ (icorgetown. Georgerown Unisersity. Sichool of Medicine, Washington. D.C.., USA
}

\begin{abstract}
Summary
Phagocytic and bactericidal function of rabbit alveolar macrophages (AMs) lavaged from animals during the course of postnatal maturation was studied. Staphylococcus aureus and a temperature-sensitive mutant of Escherichia coli, which could not replicate at $37^{\circ}$ during the functional assays, were employed as test bacteria. Assays of the phagocytic capacity of AMs from rabbits of various age groups revealed no significant differences either in the percentage of AMs which took up bacteria (79$90 \%$ ) or in the number of bacteria taken up per AM (Table 1). In contrast, bactericidal activity of $A M s$ was found to increase with increasing animal age. No bactericidal activity was detected in AMs from newborn animals (Figs. 1 and 2), whereas $A M s$ from 7-day-old animals exhibited at least a bacteristatic activity against $S$. aureus (Fig. 1) and AMs from 28-day-old rabbits showed marked bactericidal activity, essentially the same as that of AMs from adult rabbits. Adult AMs killed $75 \%$ of the $S$. aureus and $60 \%$ of the $E$. coli within $120 \mathrm{~min}$ (Figs. 1 and 2 ).
\end{abstract}

\section{Speculation}

The development of bactericidal activity in AMs during the postnatal period correlates with their previously reported morphologic and biochemical maturation. This developmental pattern of bactericidal activity may indicate that the mechanisms responsible for bacterial killing may not be fully developed at birth but develop during extrauterine life. Alternatively, the large quantities of phagocytized surfactant-like material known to be present in the $A M s$ in the early postnatal period may inhibit their bactericidal activity.

We have recently reported ultrastructural and hiochemical studies on the rabbit alveolat macrophage ( $A M)$ during animal development (23. 32). Significant ultrastructural changes were obscrved during the first postnatal month of life. including progressive development of the rough endoplasmic reticulum and Colgi complex and marked increases in the cellular content of lysosomes and mitochondria (32). Biochemical changes observed during the same period included increases in the cellular content of several lysosomal enzymes and oxidative enzymes (23). The present investigation was undertaken to examine the phagecrtic and bactericidal capabilities of $A M$ s during animal development and then to correlate these functional parameters with the previously reported ultrastructural and hiochemical findings.

\section{MATIRIAIS ANI) MITHIOLS}

\section{ANIMAIS}

AMs were ohtained from New Zcaland white rabbits of both sexes (B and H Rabbitry. Rockville. Md.). (iroups of four to six rabbits of each of the following ages were employed: 6-20 hr after hirth ( 1 day): 7 and 28 davs after birth; 9() or more days after birth (considered adult).

\section{ISOIATION OF MACROPHACIES}

AMs were obtained from animals by tratheohronchial lalvate as previousty described (32). After the lavage procedure, cell suspensions were centrifuged at $150 \times g$ for $5-10 \mathrm{~min}$ at $t^{\circ}$. then washed twice with sterile Krebs-Ringer phosphate buffer. pH 7.2. containing $206 \mathrm{mgr}^{\prime}$ glucesse and $1.5 \mathrm{mM}\left(\mathrm{a}^{\circ}\right.$ (KRP) at $4^{\circ}$. and used immediately. In order to obtain a sufficient quantity of eells, suspensions from littermates of 1-day- and 7day-old animals were pooled.

\section{PRIPARATION ()F BACTIRIAI. SUSPIENSIONS}

Staphylococcus aure'us var (openhagen (S. alureus) and lischerichia coli strain Easter ( $E$. coli). obtained from Dr. J. B. Robbins (National Institute of (Child Health and Human Development. Bethesda. Md.), were used as test organisms for assilys of phagecytic uptake and bactericidal activity. Before use, the IE coli was mutagenized chemically as described elsewhere (16). and a mutant was selected whose replication was reversibly inhibited at $37^{\circ}$. hut which grew normally at $25^{\circ}$. This mutant could be employed in the phagecytic and bactericidal assays to be described (at $37^{\circ}$ ) without the complication of rapid bacterial replication during the course of the assays.

Bacterial suspensions of these two organisms were prepared for use in assays from overnight broth cultures by washing the cultures twice in KRP and resuspending them at an optical density which yielded $2-4 \times 10^{*}$ colony-forming units $/ \mathrm{ml}$. These suspensions were kept at $4^{\circ}$ until use.

PRIPARATION ()F NORMAI. RABBIT SIRUM (NRS)

A single preparation of NRS wats obtained by pooling fresh serum from 10 addult rabbits. This preparation was divided into aliquets. stered at $70^{\circ}$. and used in all phagecytic and hatericidal assayss.

ASSAY OF PHACIOCYIC IPIAKI

Monolaters of Ails were prepared from lavage suspensions as described elsewhere (32). These monolayers were incubated with $2-4 \times 10^{\circ}$ test bacterial suspended in 4 ; NRS for 30 min at $37^{\circ}$ with gentle agitation. After the incubation period. monolayers were washed thoroughly with $0.5 "$ " Nac 1 . air-dried methanolfixed, and stained with $3 \%$ (itemsa solution. The pereentage of $A \mathrm{Ms}$ which had taken up bacteria, as well as the number of bacteria associated with each $\mathrm{AM}$. Were determined by light microscopy on duplicatc slides by examining at least ion cells on cach slide. 
RABBIT ALVI:OLAR MACROPHA(II: DF:VIILOPMINT. III.

Table 1. Phagocytic uptake of bacteria by alveslar macrophages lavaged from animals of different age's'

\begin{tabular}{|c|c|c|c|c|c|c|c|c|}
\hline & \multicolumn{2}{|c|}{1 day old } & \multicolumn{2}{|c|}{7 day old } & \multicolumn{2}{|c|}{28 day old } & \multicolumn{2}{|c|}{ - y() day old } \\
\hline & S. aure'us & E. coli & S. aureus & $i \therefore c o l i$ & S. aurcus & $E$. colli & S. aure'us & E.coli \\
\hline$\because$ Macrophages with associated hacteria & $90+52$ & $79+5$ & $85 \pm 2$ & $82 \pm 5$ & $8 x \pm 3$ & $81 \pm 3$ & $89 \pm 2$ & $x x \pm 2$ \\
\hline No. of bacteria/macrophage & $16 \pm 3^{3}$ & $8 \pm 5$ & $15 \pm 5$ & $5+3$ & $11 \pm 1$ & $6 \pm 5$ & $1+ \pm 5$ & $8 \pm 4$ \\
\hline
\end{tabular}

1 Five to nine experiments were performed in duplicate for each age group.

2 Mean + Si:M.

${ }^{3}$ Meian + SD.

\section{ASSAY OF: BACTERICIDAL AC "TIVITY}

The method of (Quic (25) was modified as follows to permit assily of the small number of $A M$ s obtainable from the younger anmals, In siliconized, sterile BELEM capsules (Emest F. Fullam Inc.. P.(). 4t4. Schenectady. N. Y.). $0.2 \mathrm{ml}$ of the washed macrophage suspension, containing $4 \times 10^{\circ} \mathrm{AMs}$. Was incubated with an equal number and volume of the test bacteria in the presence of $4 " ;$ NRS. Control incubations were performed in identical prefarations without AMs. All preparations were carried out in triplicate and incubated at $37^{\circ}$ on a Fisher RotoRack (Fischer Scientific) at $10 \mathrm{rpm}$. Aliguots were removed from each preparation at 0 . 60) and $120 \mathrm{~min}$. and serially diluted $(1: 100$ and $1: 10)$ with sterile water to lyse the AMs. using a $15-\mathrm{m}$ in incubation in cach dilution. This procedure was found to result in complete disruption of the macrophages without a decrease in colony-forming units (CFU) of bacteriat. C.U were determined on the final dilution of each aliquot, and results were expressed as a percentage of the CFU present in the zero time aliguet. At the end of the incubation period. additional alicuots were examined to determine the viability of the AMs and to checl, for any loss in the number of suspended AMs which might hate resulted from lysis or adherence. No loss of viability or decline in number of suspended $A M s$ wass detected in any preparations.

In a separate set of experiments, the effect of alveolat lining material (ALM) on the phagecytic and bactericidal functions of AMs was tested. This material has heen reported to enhance baterericidal activity in rat AMs (19). ALM was prepared from the pooled lavagates obtained from two normal adult rabbits. These lavagates were centrifuged at $200 \times g$ for 1.5 min at $t^{\circ}$ to remove the cells, and the supernatants were pooled and eentrifuged at $40.000 \times g$ for 20 min at $4^{\circ}$. The resulting pellet was resuspended in $6 \mathrm{ml} \mathrm{KRP}$ and is referred to as AI.M. Test bacteria were suspended in either ALM or KRP and incuhated for 60 min at $37^{\circ}$. Phagecytic and bactericidal assalys were then performed with AMs from 7-day-old and adult animals as described above, using these suspensions of test bacteria, both in the presence and absence of NRS.

\section{RISUITS}

The results of assalys of phagecytic uptake of test bacteria by AMs lavaged from animals of different ages appear in Table 1 . It can be seen that $85-90 \%$; of the AMs lavaged from animals of all ages tork up an average of $11-16$ s. aneress eath Similarly. 79-88\% of AMs took up an average of $5-8 \mathrm{E}$. coli each. No significant difference in either the pereentage of $A M$ s which took up bacteria or in the number of bacteria taken up per AM was found in comparing the various age groups.

The results of assays of the bactericidal activity of AMs with test bacteriat ate shown in Figures 1 and 2. It may be seen that AMs from 1-day-old rabbits failed to reduce the numbers of eithers. aureus (Fig. 1) or $E$. coli (Fig. 2) which were present at zero time and, in fact. (FU of these hacteria increased by 100\% and $30 \%$, respectively. during the incubation periods. Similar increases in (FU were observed in control preparations (which lacked AMs). AMs from 7-day-old rabbits also showed no significant ability to reduce numbers of either test bacterium within the 120-min incubation period employed. but these AMs at least partially prevented the increase in $S$. aureus observed in

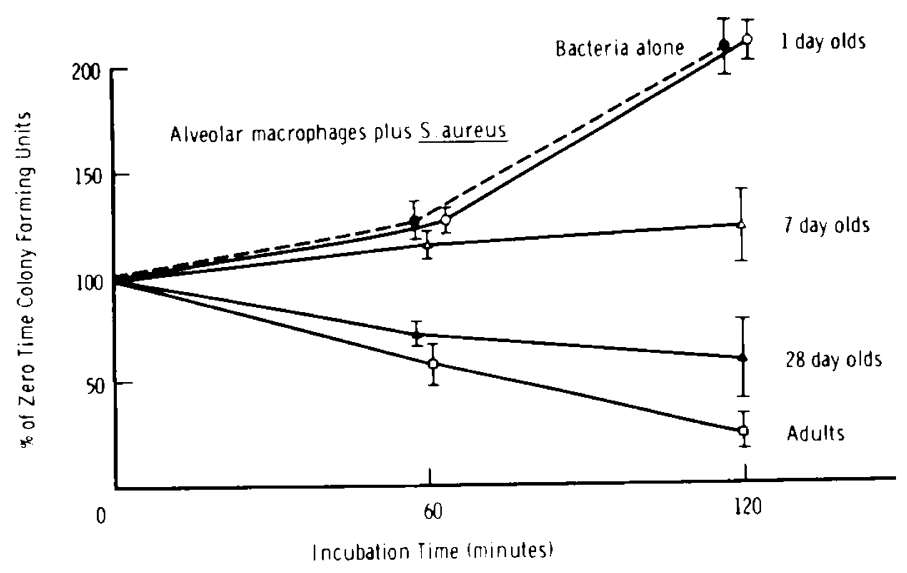

Fig. 1. Bacturicidal activity of alveolar macrophages lavaged from rabbits of different ages using $S$. aure'us as test hacterium. Five or more experiments were performed in triplicate for each age group and the values are expressed as percentage of zero time colony-forming units present (mean $\pm \mathrm{SI}: \mathrm{M}$ ).

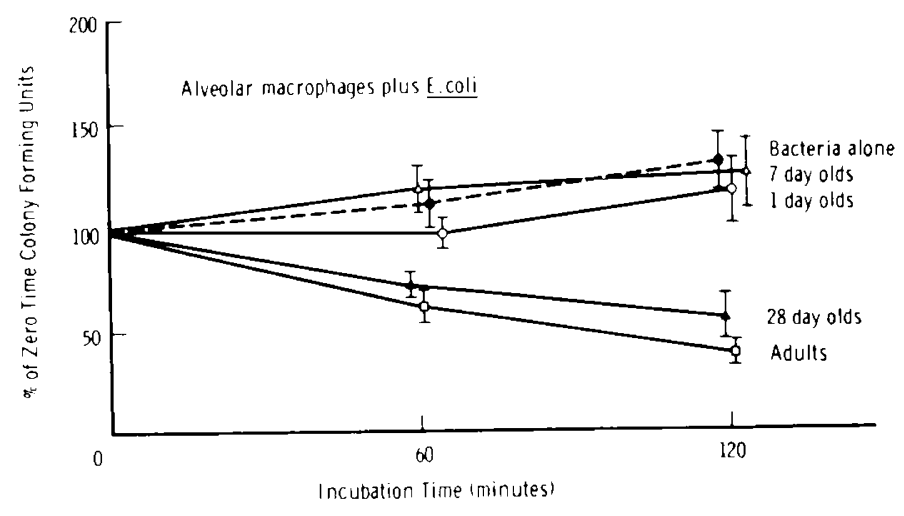

Fig. 2. Bactericidal activity of alveolar macrophages lavaged from rabbits of different ages using $t$, coli as test bacterium. Five or more experiments were performed in triplicate for ealch age group and the values are expressed as percentage of zero time colony-forming units present (mein \pm SEM).

control preparations. However. these AMs from 7-day-old animals had no measurable effect on the number of (nonreplicatting) $E$. coll (1:ig. 2). AMs from 28-day-old rabhits howed at significant bactericidal activity against both test bacteria. climinating approximately $40^{r^{\prime}}$ of the initial innoculum of either organism within 120 min (Figs. 1 and 2). AMs from adult animals showed still greater bactericidal activity. climinating $75 \%$ of the $S$. aureus (Fig. 1 ) and $60^{\circ} ;$ of the $l$. coll (Fig. 2) within $120 \mathrm{~min}$.

The results of phagocytic and bactericidal assays using test bacteria which were preinculated with AI.M were not significantly different from those reported in Table 1 and Figures 1 and 2 .

\section{DISC CUSSION}

The results of the present study indicate that lavageable AMs from rabbits of the various ages tested were highly phagocytic 
when assatyed with either $S$. aurews or $l:$ coli, and that the degree of phagocytic uptake was similar in AMs from all age groups. In contrast to phagocytic activity, hactericidal activity in AMs was found to increase with increasing animal age. Bactericidal activity was not detected in AMs from newborn animals; however. AMs from 7-day-old animals at least partially prevented the increase in CFU of $S$. aureus during the assay period. This might imply the presence of a bacteristatic activity. detectable only against rapidly replicating bacteria such as $\dot{S}$. aureas. Alternatively, this apparent bacteristatic activity could result from bactericidal mechanisms which are either incempletely developed in AMs at this time or are present in only a portion of the AM population. AMs from 28 -daty-old rabbits showed the first significant bactericidal activity against both test bacteria and this activity was similar to that found in AMs from adult animals. Employing a microscopic microbicidal technicyuc using candida albicans as a test organism. a similar pattern of microbicidal activity was observed with the $A M$ preparations from all age groups (3.3).

Two possible explanations for the observed pattern of development of bactericidal activity during animal maturation secm worthy of consideration. The first is that the bactericidal mechanisms of the AM may be fully developed at birth hut may be inhibited at this time by the large quantities of phagocytized surfactant-related material present in these cells during the carly postnatal period (23,32). Such a large phagecytic uptake in macrophages has been found to correlate with a reduction in observable lysosomes (31. 32), and has also been reported to result in the depletion of cellular energy reserves (24). effects which may interfere with normal hactericidal activity. Furthermore. macrophages loaded with erythrecytes show a decreased ability to destroy bacteria (1.3). And in fact. AMs which have ingested proteinaceous alveolar fluid, which is morphologically similar to the surfactant-related material present in the newborn AMs (32). exhibit substantially decreased microbicidal atctivity $(1+)$. A second possible explanation. not exclusive of the first. for the observed developmental pattern of bactericidal activity is that the mechanisms which are responsible for haterial killing by AMs may not he fully developed at hirth hut deselop subsequently. This explanation would correlate with in vive studies of peritoneal and tissue microphates which show : prenatal development of phagocytic function and a similar postnatal development of bactericidal mechanisms (15, 17.2628). Moreover, the postnatal development of hactericidal mechanisms in macrophages is also suggested by the reported abilits of transferred adult peritoncal macrophages to protect newborn animals against otherwise lethal infections (7).

Although the precise mechanisms involved in the bactericidal function of $A M s$ remain unsettled (1-4.6. $8-12,18,21,3(1)$. some of the morphologic changes which occur with animal development (32) (including increased development of the (iolgi apparatus. RER. lysosomes. and mitochondria) correlate with the development of this function. Moreoser. the increases in cellular content of several enzymes which oecur with animal development (23), particularly lysozyme and the enzymes of the hexosemonophosphate shunt. important in hactericidial function of the other phagocytes (18). also correlate with the development of hactericidal activity in $A M M$ s. Similar changes in hexosemonophosphate shunt enzymes have been shown forecur in human neutrophils during development $(5)$. These correlations suggest that the morphological changes and the increases in cellular enzyme content may in part be related to the maturation of bactericidal activity in $A . M$ s and are similar to those reported in $B C(B$-stimulated $A . M$, which also have increased bactericidal activity (9, 20, 22, 29). The possible implications of these findings in AMs after birth may be important in explaining the high frequency of respiratory infections characteristic of the newborn animal.

\section{RHFIREN(YS ANI) NOTHS}

1. Allen, R. ('.. Stjernholm, R. I... and Sicele, R. H.: Ividence for the generation of an clectronic excitation statte(s) in human polymorphonuclear leukecyles and its participation in bactericidal activity. Biuchem. Biophys Res. Commun., 47: 674)(1472).

2. Axline, $s$, (i.: Functional biochemistry of the macrophage. Semin. Hematol, $7: 1+2(1970)$

3. Bathior. B. M.. Kipnes, R. S.. and curnutte, J. T.: Bislegical defense mechansme: the production hy leukocites of superoxide. a potential bactericidal agent. J. (lin. Invest. 52: 741 (1973).

4. Beckerdite. S.. Mooney. (.. Weiss, J. Franson. R., and I:lsbach, P.: Farly and discrete changes in permeability of Fecherichia coli and certain wher gram-negative hacteria during killing by granulecetes. J. Fap. Med.. 1 to $396(1474)$

5. Bellanti. J. A.. Cantz. B. I.. Yang. M. (.. Thadden. H.. and Schlegel, R $J$.: Biochemical changes in human polymorphonuclear leukecyter during maturation. In: J. A. Bellanti, and D). H. Datyton: The Phagecitic (cll in Host Resistance. p. 321 (Raten Press. Hewlet, N. Y.. 1975)

6. Biggar. D. W. and Sturgess. J. M.: Perenxidase atetivity of alveolar materophages. Lat. Invest...34:31(1976)

7. Blatese, M. R.: Macrophages and the development of immunocompetence In: J. A. Bellanti, and D. H. Dayton: The Phagecytic (ill in Hos Resistance. P. 304 (Raven Press. Hewlet. N. Y. 1975 )

. Cohn. Z. A.: The structure and function of monocytes and macrophages Advan. Immunol. 4: $16.3(1968)$

4. Dannenterg. A. M.. Jr.: (ellular hypersensitivity and cellular immunity in the pathogenesis of tuherculosis: Specificity, systemic and local nature, and associated macrophage enzymes. Bacteriol. Rev.. 32: $85(1968)$.

10. D. (hatelet, I. R. . Wang. P.. and McCall. ( . 1 ... Bactericidal mechanism of macrophages. In: D). Schlessinger: Microbiolegy 1975. p. 215 (American Society of Microbiology. Washington. D. ( . . 1975).

11. Drath. D. B.. and Karnowsy. M. I..: Bactericidal activity of metal-mediated peroxide-ascorbate systems. Infect. Immun. I0: 1077 (1974).

12. Franson. R.. Beckerdite. S.. Wang, P. Waite. M. and IIsbach. P.: Some propertics of phospholipases of alveolar macrophages. Biochem. Biophes Acta. 296: $365(1973)$.

13. (iill. F. A.. Katye. D). Hook. I. W.: The influcnce of erythrophagecrtonis on the interaction of macrophages and Salmonella in vitro. J. Fxp. Med.. 124. $17.3(1966)$

14. Colde, D. W.. Territu. M. Finley. I. N.. and ( line, M. J.: Defective lung macrophages in pulmonary alvedar proteinosis. Ann. Intern. Mad. 85 $304(1976)$.

15. Hardy. B.. Skutelsky. F... (iloheron. A.. and Danon. D.: LIterastructurat differences between macrophages of newhorn and adult mice. J. Reticuler endothel. Soc.. 19: 291 (1976).

16. Honke, A. M., Zeligs. B. J. ()eschger, M. P., and Bellanti. J. A. Exchericha coli strain faster $E / 2 / 64: A$ temperature-sensitive target for use in bactericidal assays. (In preparation.)

17. Karthigasu. K.. Reade. P. ('.. and Jenkin. ( . R.: The functional development of the reticulo-endothelial swstem. III. The hatctericidal capacity of fixed matrophages of foctal and neonatal chicks and rats. Immunology, 9:67 (1965)

18. Klebanoff. S. J.. and Hamen. ( . B.: Antimicrohial whtem of mononucleat

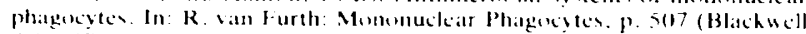
Scientific Publications. ()xford. 1975).

14. L.aforee, F. M. Kelley, W. J. . and Haber. (j. I .. Inactivation of staphylococe by alvoolar macrophages with preliminatry observations on the impertance of alseolar lining material. Amer. Rew. Resp. Dis.. 128: $784(1973)$

20. Leake. F. S.. and Myrvik. ( $)$. N.: ('hanges in morphology and in lyourmo content of frece atverolar cells after intravenous injection of killed BC $\mathrm{C} ;$ in

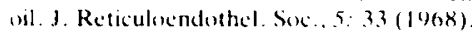

21. Miller. Г. E.: Killing and lysis of gram negattive bacteriat through the syergistic effect of hydrogen peroxide. ascorbic acid. and lysozme, J Bacteriol. 48: $949(1969)$

22. Myrvik. Q. N.: The role of the alveolar macrophage. J. ()ccup. Med., 15 $190(197.3)$

23. Nerurkatr. L.. S., Zeligs. B. J., and Bellanti. J. A.: Matturatton of the rabhit alveolar macrophage during animal development. II. Biochemical and enzymatic studies. Pediat. Res., 11: 1202 (1977).

24. North. R. J.: The uptake of particulate antigens. J. Reticuloconderthel Six.. 5. $20.3(1968)$

25. Quic, P. G., White, J. G.. Holmes, B.. and Geod, R. A.: In vitro bactericidat capacity of human polvmorphonuclear leukocites: Diminished activity in

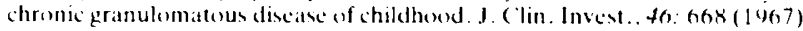

26. Reade. P. (.$:$ The development of bactericidal atctivity in rat peritoneal macrophatges. Aust. J. Ixp. Biol. Mcd. Sce. 46: 231 (1968).

27. Reade, P. ( ... and (asley-Smith, J. R,: The functional development of the reticuloendothelial system. Il. The histology of blood clearance by the fixed macrophages of foetall rats. Immunology, $9: 61$ (1965).

28. Reade. P. ( .. and Jenkin, $(., R$ : The functional development of the reticulerendothelial ystem. I. The uptake of intravenously injected particle by foctal rats. Immunology. 4: 53 (196.5)

29. Sorter. W. A. I eake, F. S.. and Myrvik, (). N.: (omparative densities of hydrolate-containing granules from normal and $B(C)$-induced alveolar macrophages. Infect. Immun.. 7: 86 (197.3).

30. Strauss. R. R.. Paul. B. B. Jacobs. A. A. and Shara, A. J : Role of the phagecyte in host-parasite interactions. XXVII. Mycloperoxudase relationships to antimicrobial activity. Infect. Immun.. 3. 545 (1471).

31. Sutton. J. S.. and Weiss. 1... Transformation of monocytes in tissue culture inte macrophages, epithelisid cells, and multinucleated giant cells. J. (ill Biol. 28: 3033(1966).

32. Zecligs, B. J.. Zeligs. J. D.. Nerurkar, I. S.. and Bellanti, J. A.: Maturation of the rabbit alveolar matcrophage during animal development. I. Perinatal 
influx into alveoli and ultrastructural differentiation. Pediat. Res.. 11:197 (1977)

3.3. Zeligs, B. J.. Nerurkar. I. S., and Bellanti, J. A.: Increase in fungicidal activity of rabbit alveolar macrophatges during animal development. (ln prepiration.)

34. This rescarch was supporled by National Institutes of Health (irant HI.-
$1674 x$

i5. Reyuest for reprints should be addressed to: Barharat J. Zeligs. Department of Pediatric Room 130 Gorman Bldg. (Georgetown University School of Medicine. 38000 Reservoir Road, N. W. Washington. D.C. 20007 (USA). 36. Recived for publication February 22, 1977.

37. Accepted for publication March 30, 1977

\title{
Partially Restricted Antitoxins of Tetanus and Diphtheria in Man
}

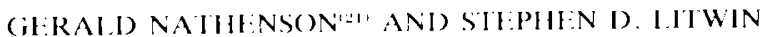 \\ Departme'nt of Pediatrics, Montefiore Hospital and Medical Center and the Albert Finstein Colle'ge'of Medicine \\ Bromx, and Department of Medicine (Cienetics). New York Hospital, and the Cornell Medical college'. New \\ York. New York. LiS
}

\section{Summary}

Antibodies of restricted specificity have been identified in the human in response to certain antigens. The present study analyzed tetanus and diphtheria antitoxins isolated from selected human sera and suggested a restricted reponse in antibody production to each of these antigens. Purified antibodies from eight serum specimens with elevated hemagglutination titers to tetanus and four to diphtheria yielded only $\operatorname{lgG}$ proteins in concentrations of $160-500 \mu \mathrm{g} / \mathrm{ml}$. Although some of the tetanus specimens were derived from cord sera and tetanus immunoglobulin, none of the total group had antibodies of the $\lg \mathrm{A}$ and IgM classes. Utilizing immunoelectrophoresis against heavy chain subclasses, genetic markers, and $\kappa$ and $\lambda$ quantitations, a predeliction for the $\kappa$ IgG, subclass was established for both tetanus and diphtheria antibodies. The $\lambda$ light chains were present in diminished quantities, IgG, heavy chains were absent, and the $\operatorname{IgG} G_{i}$ and $\operatorname{IgG}$, chains were variably identified.

\section{Speculation}

The elucidation of those antigens which result in restricted antibody formation has apparent clinical significance, in view of the fact that some individuals possess selective defects in the production of certain $\operatorname{lgG}$ subclasses.

The light and heary chain differences cause human immunoglobulins of each of the classes to exist in several forms. in accordance with variations in the way in which these chains combine. Since $\lg (i$ heavy chains, as an example, occur in four subclasses $\left(\lg \left(j_{1}, \lg \left(j_{2}, \operatorname{Ig}\left(j_{3,}\right.\right.\right.\right.$. and $\lg \left(j_{1}\right)$ and the light chains in two types $(\kappa$ and $\lambda)$, eight different $\lg ($ i molecules are possible by varying combinations of light and heavy chains. Normally. the Ig( $i_{1}$ subclass constitutes about $60 \%$ of total $\lg (j .23 \%$ $\lg \left(i_{2}, 7 \% \lg B_{3,}\right.$, and $4 \% \lg \left(i_{1}\right.$. When combined with the $\lg \theta_{1}$ chain, the light chain $\kappa: \lambda$ ratio is about $2: 1$

Although most antibodies produced in the human appear to be hetcrogeneous, the response to certain antigens may result in antibody immunoglobulin which is relatively or even completely restricted. Rh antibody, as an example is primarily an $\lg G_{1}$ immunoglobulin with some $\lg G_{3}$ and $\lg f_{4}$ but no $\lg i_{2}$ molecules (5. 10). whereas bacterial polysaccharide antigens clicit predominantly $\lg (; .2$ production (7). Antibodies against factor V'Ill are formed preferentially within the $\operatorname{Ig}\left(j_{4}\right.$ subelass (1). Levan prowetes a highly restricted manufacture of $\kappa \operatorname{lgG}_{2}$ globulins. approaching the homogeneity of a myeloma protein (17).

Utilizing available immunologic techniques criteria have been proposed for establishing antibody specificity (3. 16). Fmploying several of these criteria, the results of this investigation suggest that the human responds with partial antibody restriction to the toxins of (lostridium tetani and Corvebacterium diphthe' ria.

\section{MATLRIALS AND MFTHODS}

light specimens containing tetanus antibodies were derived from three sources: five were samples of newborn cord sera. two were taken from human antitctanus immunoglobulin pools, and one was serum of a 5 -year-old burn patient taken several wecks after a tetanus toxorid booster immunization. Four scra containing diphtheria antibodies were from children, aged 7 months to 11 vears. with recent clinical diphtheria. Specimens were obtained within a period not exceeding 6 months from the time of active discase. Antibody titers to tetanus and diphtheria in sera and in purified antibody preparations were measured by a hemagglutination technique using the toxoids of either antigen coupled to human type () Rh' red blood cells by the chromic chloride method (2).

Purified antibody preparations were prepared in the following manner. Tetanus or diphtheria toxoid (Wyeth. aluminum-precipitated toxoid containing $0.01 \mathrm{mg}$ protein $\mathrm{N} / \mathrm{ml}$ for tetanus and $0.0(04 \mathrm{mg}$ protein $\mathrm{N} / \mathrm{ml}$ for diphtheria) $(3-4 \mathrm{ml})$ was incubated with $1 \mathrm{ml}$ serum for $1 \mathrm{hr}$ at $37^{\circ}$. then refrigerated wernight. The precipitate was watsed 12 times. The supernatant and early Washes were discarded after being tested for specific antibedy activity. The precipitate was then incubated with acid-glecinc buffer. pH $3.0(1 \mathrm{ml})$. Wernight at rom temperature. The supernatant was dialyed against normal saline for $1 \mathrm{hr}$ and the residual material discarded. The dialysate (about $1 \mathrm{ml}$ in quantity). representing a purified antibody preparation. Was used for subsequent analyses. 